УДК 624.012 .45

DOI https://doi.org/10.32838/2663-5941/2020.4/38

Орлова О.М.

Уманський державний педагогічний університет імені Павла Тичини

\title{
ЕКСПЕРИМЕНТАЛЬНІ ДОСЛІДЖЕННЯ \\ ЗАЛІЗОБЕТОННИХ ДВОТАВРОВИХ ЕЛЕМЕНТІВ ІЗ НОРМАЛЬНИМИ ТРІЩИНАМИ ПРИ КРУЧЕННІ
}

Наведені дані експериментальних досліджень міџності і жорсткості залізобетонних двотаврових елементів із нормальними тріщинами в процесі дії на них крутного моменту. Показано, що залежність «крутний момент -кут закручування» є практично лінійною. Суттєві нелінійні деформації з'являються на останніх етапах навантаження перед руйнуванням. Тому при нормативних крутних моментах рекомендовано вважати роботу залізобетонних елементів двотаврового поперечного перерізу з нормальними тріщинами лінійною. Показано, щзо наявність поздовжньої арматури впливає на міцність і жорсткість балок із нормальними тріщинами. Доволі велику частину зовнішнього крутного моменту сприймають нагельні сили в поздовжній арматурі. Різницю між зовнішнім крутним моментом і моментом нагельних сил в арматурі сприймає верхня полка двотаврового елементу. За відсутності поздовжньої арматури верхня полка може руйнуватись при навантаженнях, набагато менших, ніж руйнуюче навантаження балок із поздовжньою арматурою. Армування експериментальних балок із нормальними тріщинами тільки поздовжньою арматурою суттєво впливає на їх жорсткість. На міџність при крученні поздовжня арматура елементів із нормальними тріщинами впливає не так суттєво, як на жорсткість.

Збільшення діаметра поздовжньої арматури призводить до зменшення деформацій $і$ відповідно збільшення жорсткості балок при крученні. На основі експериментальних досліджень $і$ з огляду на попередні теоретичні дослідження автора спростовано давню думку, що поздовжня арматура не впливає на міцність при крученні. Наведені факти, на погляд автора, мають бути враховані під час практичних розрахунків несучих систем залізобетонних будівель і споруд.

Ключові слова: двотавровий елемент, кручення, нормальні тріщини, жорсткість і міџність при крученні, поздовжня арматура, нагельна сила.

Постановка проблеми. Відомо, що врахування просторової роботи багаторазово статично невизначених систем (перекриття, мости, каркаси будівель) дає змогу істотно уточнити зусилля, що виникають в окремих елементах складної системи. Відомо також, що перерозподіл зусиль між окремими елементами статично невизначених систем залежить від співвідношення згинальних і крутильних жорсткостей цих елементів [1]. Водночас у залізобетонних статично невизначених системах на згинальну і крутильну жорсткості впливає утворення різних тріщин (нормальні, похилі, просторові, тріщини відриву та ін.). Нормальні тріщини утворюються вже на невисоких рівнях навантаження. Утворення тріщин тягне за собою стрибкоподібну зміну жорсткості елемента, при цьому жорсткість може зменшитись в кілька разів.

При досить широкій вивченості жорсткості залізобетонних елементів при згині їх жорсткість і міцність при крученні мало вивчена. При цьому основна увага в наукових роботах i нормативних документах, присвячених роботі залізобетонних елементів при крученні, приділена елементам із просторовими (спіральними) тріщинами $[4 ; 5 ; 9 ; 11 ; 12]$. Однак, експериментальними i теоретичними дослідженнями було показано [1; 3; 10], що нормальні тріщини також істотно впливають на жорсткість при крученні стрижневих залізобетонних елементів. У роботах $[1 ; 3 ; 6 ; 7 ; 8]$ розглянуті чисельні і наближені методики визначення крутильних жорсткостей елементів прямокутного, таврового, коробчастого і порожнистого трикутного перерізів. У роботі [2] розглянуті питання розрахунку жорсткості та міцності залізобетонних двотаврових елементів при крученні. Експериментальним дослідженням роботи залізобетонних елементів прямокутного, коробчастого i порожнистого трикутного перерізу присвячені публікації [6-8]. Однак експериментальні дослідження жорсткості і міцності залізобетонних двотаврових елементів із нормальними тріщинами при крученні не проводилися. 
Постановка завдання. Метою статті є експериментальне дослідження міцності і жорсткості залізобетонних двотаврових елементів із нормальними тріщинами при крученні.

Виклад основного матеріалу дослідження. У процесі експерименту передбачалося дослідити крутильну жорсткість і міцність залізобетонних елементів двотаврового перетину з нормальними тріщинами на моделях. Були виготовлені зразки 3 розмірами, показаними на рис. 1.

Метою досліджень було встановлення характеру зміни характеристик жорсткості зразків із різними діаметрами поздовжньої арматури і різними розмірами поперечного перерізу. Через те, що автором теоретично було встановлено, що для двотаврових елементів із малою товщиною стінки висота тріщини грає не істотну роль, було прийнято рішення прийняти однакову висоту нормальної тріщини, яка дорівнює половині висоти перерізу елемента, а варіювати розмірами поперечного перерізу та діаметром арматури.

Штучні нормальні тріщини були створені за допомогою пластинок 3 оргскла, які вставляли в місці розташування тріщини при укладанні бетону в опалубку. Такі тріщини поділяли зразки за довжиною на окремі блоки, пов' язані між собою частиною бетону без тріщин і поздовжньою арматурою (рис. 2). Довжина блоків становила 300 мм. Крім того, три зразки були зроблені суцільними, без штучних нормальних тріщин.

Ширина нижньої полиці для всіх зразків була однаковою і становила 85 мм, її товщина - 45 мм. Товщина ребра також не варіювалася і дорівнювала 30 мм. Висота зразків становила 220 мм. Варіювалися ширина $b_{f}$ i товщина $h_{f}$ верхньої полиці, а також діаметр поздовжньої арматури. Верхня полиця не була армована сіткою для виключення впливу арматури 3 метою більш точного визначення iï міцності і впливу нагельної сили в поздовжній арматурі на міцність і жорсткість елемента при крученні. Загалом було випробувано 9 балок iз штучними нормальними тріщинами і 3 балки без тріщин для порівняння.

Для аналізу експериментальних даних і встановлення залежності між параметрами деформування (кутом закручування блоків, відокремлених тріщинами) i величиною зовнішнього навантаження були побудовані графіки «крутний

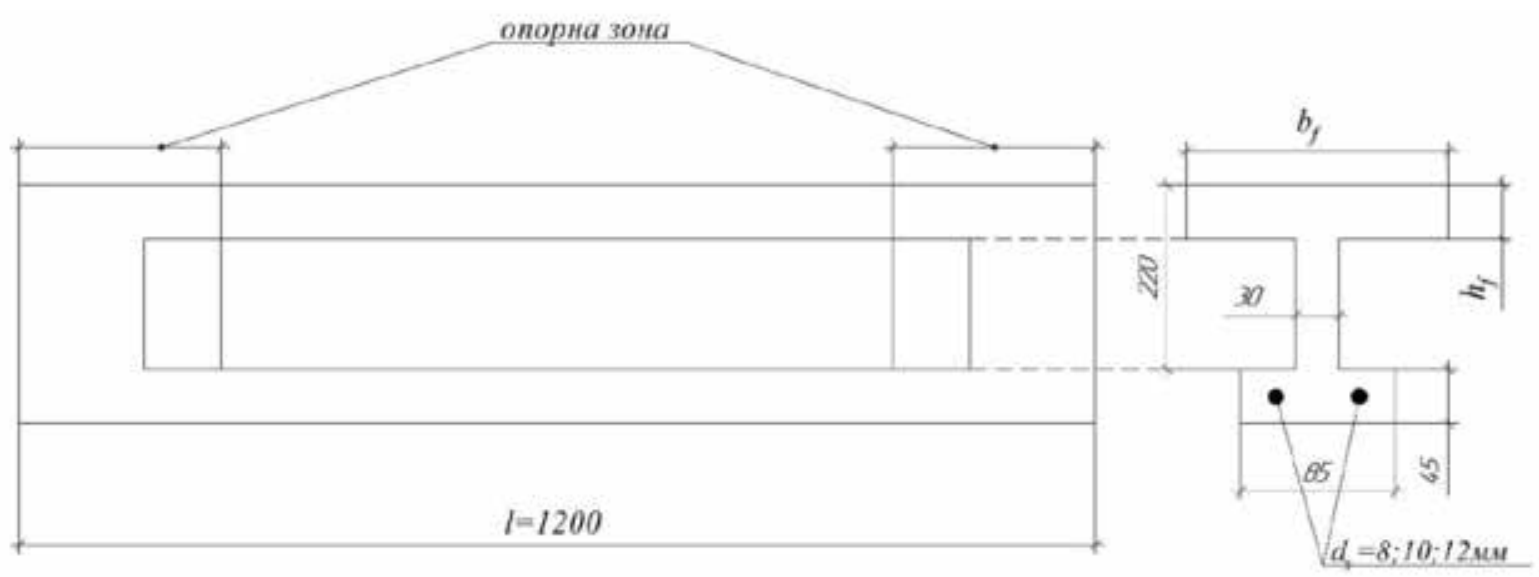

Рис. 1. Розміри експериментальних зразків

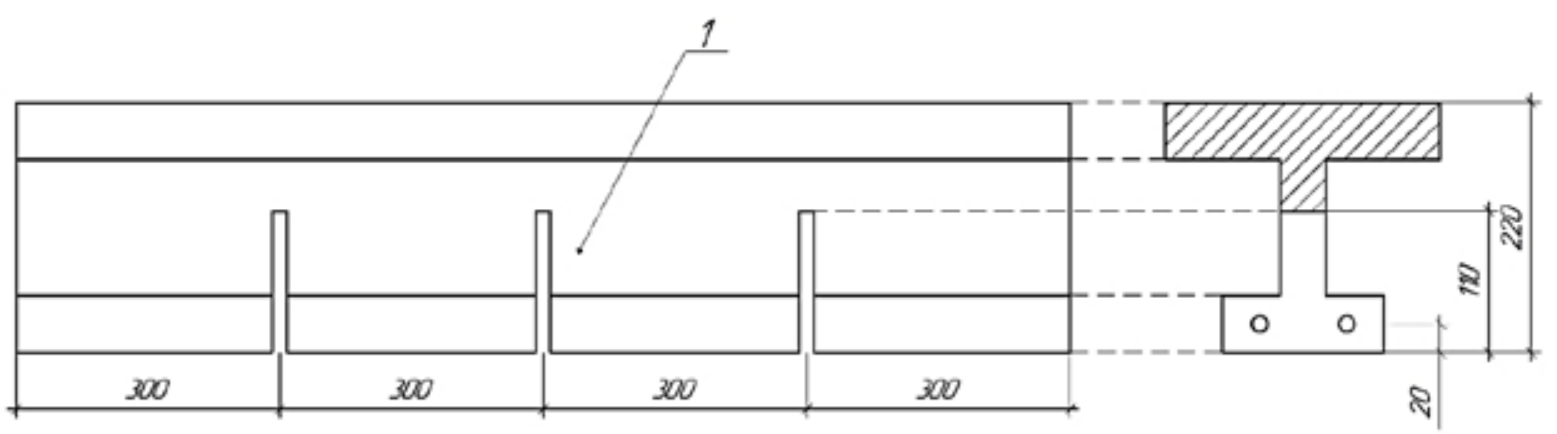

Рис. 2. Схема утворення штучних тріщин і армування зразків; 1 - вставка з оргскла 
момент-кут закручування». На рис. 3-5 для прикладу наведені такі графіки для деяких випробуваних балок.

На рисунках 3-5, окрім залежностей «крутний момент-кут закручування», показані максимальні значення крутного моменту $\mathrm{M}_{\max }$, тобто руйнуючого крутного моменту. На передостанніх етапах навантаження прибори для вимірювання були прибрані для попередження їх руйнування, тому значень кутів закручування при руйнуванні немає.

3 графіків можна бачити, що залежність «крутний момент - кут закручування» $€$ практично лінійною. Суттєві нелінійні деформації з'являлися на останніх етапах навантаження перед руйнуванням. Тому при нормативних навантаженнях можна вважати роботу зразків лінійною.

Балка 3 розмірами $\mathrm{b}_{\mathrm{f}}=300$; $\mathrm{h}_{\mathrm{f}}=40 ; \mathrm{ds}=12$ (див. рис. 5) була передчасно крихко зруйнована від виколювання поздовжньої арматури, що скоріш за все $\epsilon$ недоліком пї бетонування. Тому ii руйнуючий момент значно менший за руйнуючі моменти інших балок цієї ж серії.

Картина тріщиноутворення усіх зразків із штучними нормальними тріщинами мала подібний характер. Із вершини штучної тріщини 3'являлася похила тріщина, яка поширювалась до верхньої полиці балки. Надалі картина кілька етапів навантаження оставалася незмінною. У деяких зразках відбувалося відшарування бетону біля поздовжньої арматури, але це не впливало на міцність зразків, за виключенням зразка (див. рис. 5). При подальшому навантаженні у верхній полиці балки з'являлася просторова тріщина. При цьому деформації суттєво збільшувалися, після чого наставав момент руйнування балки.

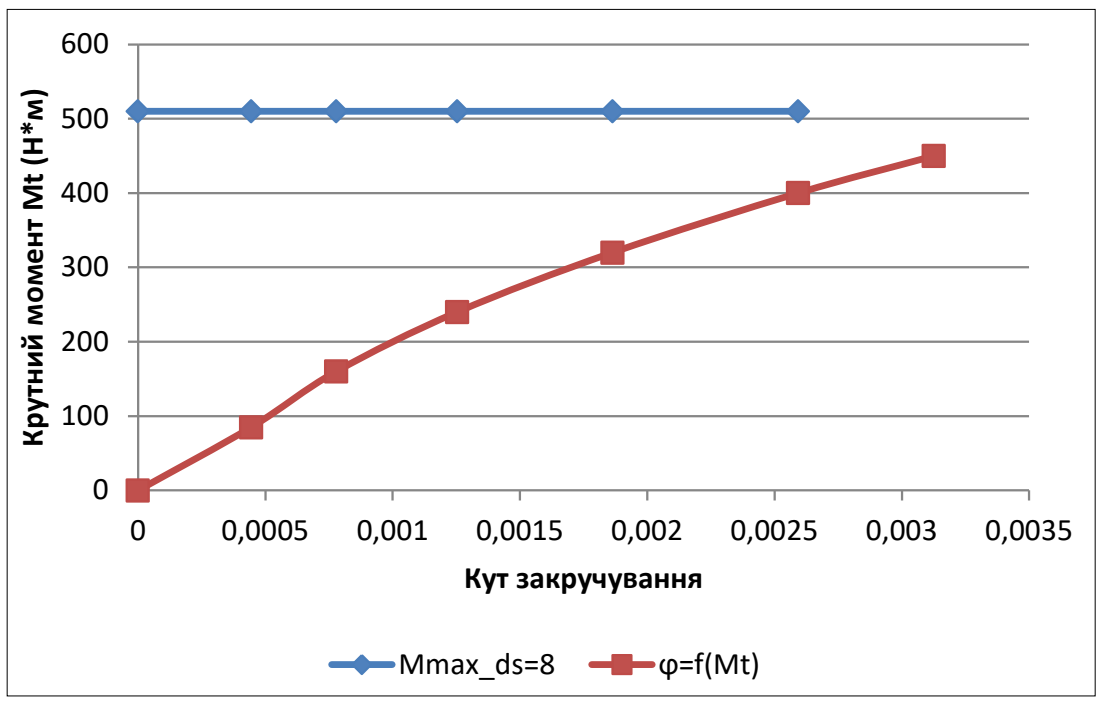

Рис. 3. Кути закручування і руйнуючі моменти для балки 3 розмірами: bf $=300 ;$ hf $=30 ; d s=8$

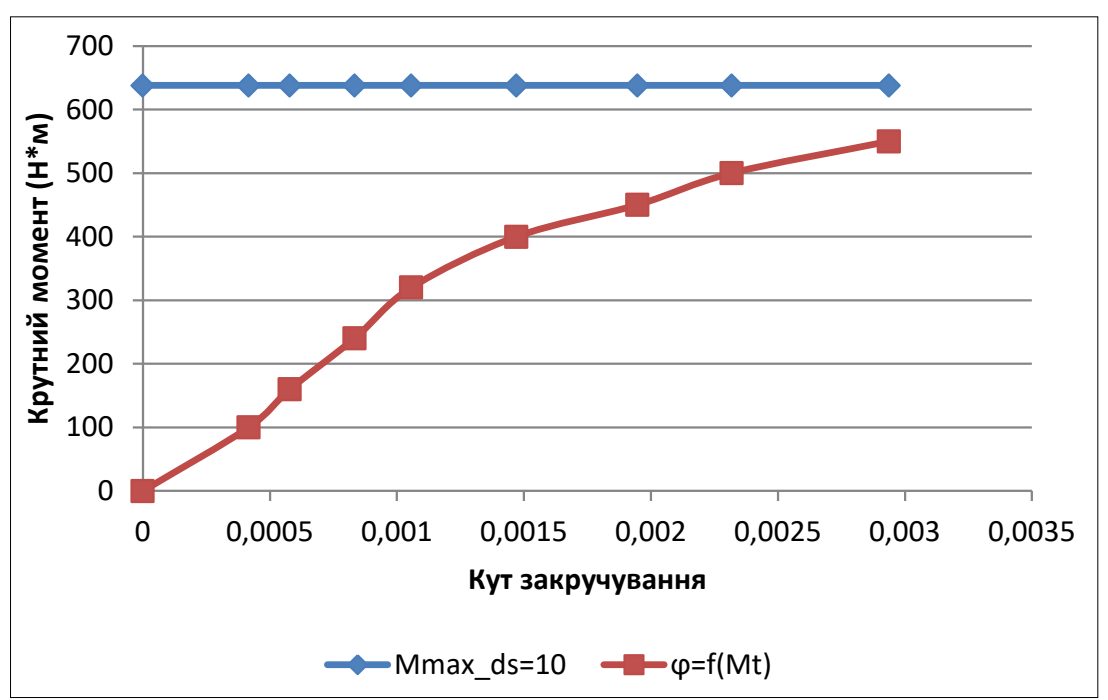

Рис. 4. Кути закручування і руйнуючі моменти для балки з розмірами: $b f=300 ;$ hf $=40 ; \mathrm{ds}=10$

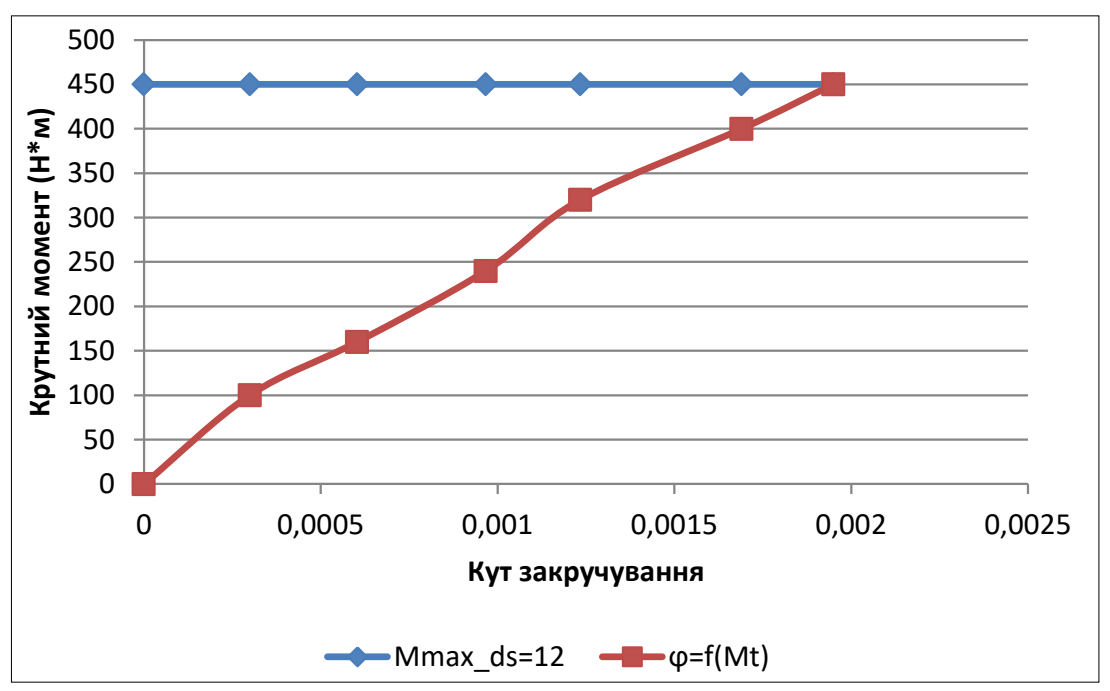

Рис. 5. Кути закручування і руйнуючі моменти для балки зозмірами: $b f=300 ;$ hf $=40 ; d s=12$ 
На рис. 6 показано загальний вигляд похилої тріщини з початком у вершині штучної нормальної тріщини.

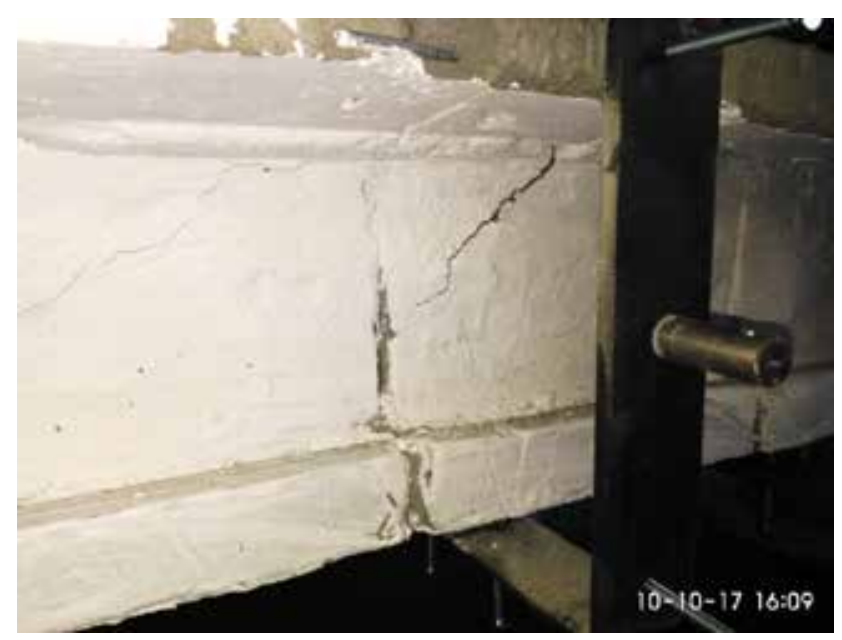

Рис. 6. Похила тріщина від вершини штучної нормальної тріщини в балці

На рис. 7-8 показано загальний вигляд балок у процесі руйнування.

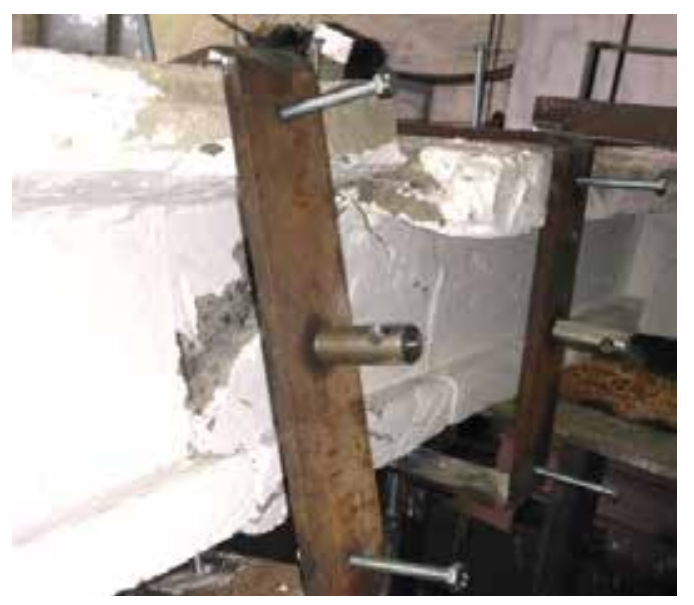

Рис. 7. Руйнування балки

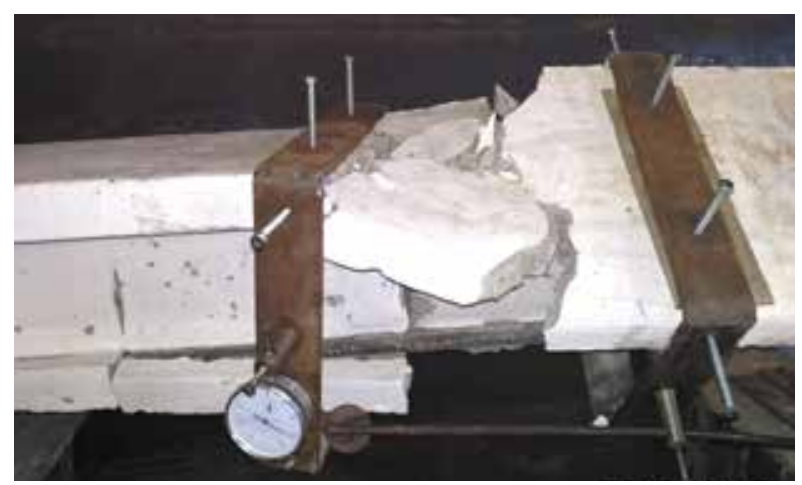

Рис. 8. Передчасне руйнування балки від виколювання поздовжньої арматури
Аналізуючи експериментальні дані, можна констатувати, що наявність поздовжньої арматури впливає на міцність і жорсткість балок із нормальними тріщинами. Доволі велику частину зовнішнього крутного моменту сприймають нагельні сили в поздовжній арматурі. Різницю між зовнішнім крутним моментом і моментом нагельних сил в арматурі сприймає верхня полка двотаврового елементу. За відсутності поздовжньої арматури верхня полка може руйнуватись при навантаженнях, набагато менших, ніж руйнуюче навантаження балок із поздовжньою арматурою. Цей факт підтверджує і передчасне руйнування балки, яка описана вище, від виколювання поздовжньої арматури.

На відміну від балок із штучними нормальними тріщинами в балках без тріщин спочатку з'являлися похилі тріщини в ребрах. Потім ці тріщини ширились у нижню і верхню полицю. У верхній полиці з'являлася просторова тріщина. При цьому деформації різко зростали. Після цього балки руйнувалися в результаті втрати несучої здатності верхньої полиці. Руйнуючі моменти балок без тріщин були дещо більшими, ніж моменти балок із тріщинами.

Висновки. Експериментальними дослідженнями встановлено, що діаграма «крутний момент - кут закручування» залізобетонних елементів двотаврового перерізу 3 нормальними тріщинами до високих рівнів навантаження має лінійний характер. Пластичні деформації мають місце на останніх етапах завантаження, перед руйнуванням. Основним типом руйнування є руйнування верхньої полиці двотаврового елементу 3 розвитком просторової тріщини кручення.

Армування експериментальних балок із нормальними тріщинами тільки поздовжньою арматурою суттєво впливає на їх жорсткість. На міцність при крученні поздовжня арматура елементів із нормальними тріщинами впливає не так суттєво, як на жорсткість. Доволі велику частину зовнішнього крутного моменту сприймають нагельні сили в поздовжній арматурі. Різницю між зовнішнім крутним моментом і моментом нагельних сил в арматурі сприймає верхня полка двотаврового елементу.

Збільшення діаметра поздовжньої арматури призводить до зменшення деформацій i, відповідно, збільшення жорсткості балок під час кручення. Збільшення жорсткості і міцності верхньої полиці впливає як на загальну жорсткість балок, так і на їх міцність.

Дослідження показують, що міцність залізобетонних елементів при крученні залежить від перерізу поздовжньої арматури в разі наявності нормальних тріщин, що спростовує давню думку, що поздовжня арматура не впливає на міцність при крученні. Наведені факти, як вважає автор, мають 
бути враховані під час практичних розрахунків несучих систем залізобетонних будівель і споруд.

Перспективою досліджень $є$ розроблення практичних рекомендацій для проектування залізо- бетонних двотаврових елементів із нормальними тріщинами в процесі дії на них крутних моментів із врахуванням попередніх теоретичних розробок автора та експериментальних досліджень.

\section{Список літератури:}

1. Азизов Т.Н. Жесткость железобетонных элементов при кручении и ее влияние на пространственную работу мостов. Механіка і фізика руйнування будівельних матеріалів та конструкцій : Збірник наукових праць. НАН України. Фізико-мех. інститут ім. В.Г. Карпенка. Львів, 2009. С. 576-590.

2. Азизов Т.Н. Крутильная жесткость железобетонных двутавровых балок с многорядным армированием при наличии нормальных трещин / Т.Н. Азизов, О.М. Орлова, Е.В. Нагайчук. Sciences of Europe. 2019. Vol. 1, № 36. Р. 35-39.

3. Азизов Т.Н. Определение крутильной жесткости железобетонных элементов с трещинами. Дороги і мости. Збірник наукових праць. Київ : ДерждорНДІ, 2007. Вип. 7. Том 1. С. 3-8.

4. Карпенко Н.И. Теория деформирования железобетона с трещинами. Москва : Стройиздат, 1976. 208 с.

5. Коуэн, Г.Дж. Кручение в обычном и предварительно напряженном железобетоне: Пер. с англ. Москва : Изд-во литературы по строительству, 1972. 104 с.

6. Мельник О.В. Крутильна жорсткість та міцність залізобетонних елементів коробчастого перерізу 3 нормальними тріщинами : автореф. дис. ... канд. техн. наук : 05.23.01 / Одеська державна академія будівництва та архітектури. Одеса, 2012. 22 с.

7. Мельник О.С. Жорсткість та міцність залізобетонних елементів порожнистого трикутного перерізу 3 нормальними тріщинами при крученні : автореф. дис. ... канд. техн. наук : 05.23 .01 / Одеська державна академія будівництва та архітектури. Одеса, 2013. 24 с.

8. Срібняк Н.М. Крутильна жорсткість залізобетонних елементів перекриттів із нормальними тріщинами : автореф. дис. ... канд. техн. наук : 05.23 .01 / Одеська державна академія будівництва та архітектури. Одеса, 2009. $23 \mathrm{c}$.

9. ACI 318-11, Building Code Requirements for Structural Concrete and Commentary (ACI 318M-11), American Concrete Institute, Farmington Hills, 2011.

10. Azizov T. Calculation of reinforced concrete ceilings with normal cracks accounting the Chebyshev approximation / T. Azizov, O. Melnik and others. 6 th International Scientific Conference "Reliability and Durability of Railway Transport Engineering Structures and Buildings" Transbud-2017. Kharkiv, April 19-21, 2017. S. 1-7.

11. BS EN 1990:2002+A1:2005, Eurocode: Basis of Structural Design (includes Amendment A1:2005), (2002) 21.

12. Kochkarev D. Bending deflection reinforced concrete elements determination / D. Kochkarev, T. Azizov and T. Galinska. Published online: at the MATEC Web of Conferences, 16 November 2018.

\section{Orlova O.M. THE EXPERIMENTAL RESEARCHES OF REINFORCED CONCRETE I-BEAM ELEMENTS WITH NORMAL CRACKS WHEN TURNING}

The data of experimental researches of the rigidity of reinforced concrete I-beam elements with normal cracks at the action on them of the twisting moment have resulted in this paper. It is shown that the dependence "torque-twist angle" is almost linear. Significant nonlinear deformations appear in the last stages of loading before failure. Therefore at normative torques, it is recommended to consider the work of reinforced concrete elements of the I-beam cross-section with normal cracks linear. It is shown that the presence of longitudinal reinforcement affects the strength and rigidity of beams with normal cracks. Quite a large part of the external torque is perceived by the pin forces in the longitudinal reinforcement. The difference between the external torque and the moment of the pin forces in the armature is perceived by the upper shelf of the I-beam element. In the absence of longitudinal reinforcement, the upper shelf can collapse at loads much smaller than the destructie load of beams with longitudinal reinforcement.

Reinforcement of experimental beams with normal cracks only by longitudinal reinforcement significantly affects their rigidity. The torsional strength of the longitudinal reinforcement of elements with normal cracks does not affect as significantly as the stiffness. Quite a large part of the external torque is perceived by the nail forces in the longitudinal reinforcement. The difference between the external torque and the moment of the nail forces in the armature is perceived by the upper shelf of the I-beam element. Increasing the diameter of the longitudinal reinforcement leads to a decrease in deformation and, accordingly, an increase in the stiffness of the beams during torsion. Based on experimental researches and taking into account previous theoretical researches of the author the long-existing opinion that longitudinal armature does not influence durability at torsion is refuted. These facts, in the opinion of the author, should be taken into account when conducting practical calculations of load-bearing systems of reinforced concrete buildings and structures.

Key words: I-beam, torsion, normal cracks, torsional strength, longitudinal reinforcement, pin force. 